The final version of this paper was publishing in Analyse \& Kritik 2018, 40(2).

Author: Justin P. Holt

Title: Moral Objectivity and Property: The Justice of Liberal Socialism

Abstract: This paper restates the thesis of The Requirements of Justice and Liberal Socialism where it was argued that liberal socialism best meets Rawlsian requirements of justice. The recent responses to this paper by Jan Narveson, Jeppe von Platz, and Alan Thomas merit examination and comment. This paper shows that if Rawlsian justice is to be met, then nonpersonal property must be subject to public control. If just outcomes merit the public control of non-personal property and this control is not utilized, then justice has been subordinated to the objectively less important institution of private property.

\title{
Introduction
}

This paper is my response to the articles that Jan Narveson (2017), Jeppe von Platz (2017), and Alan Thomas (2017) wrote considering The Requirements of Justice and Liberal Socialism (Holt 2017). I will discuss their articles individually. Before I begin I would like to thank them for their insightful, interesting, and sincere comments they wrote in response to my work. I greatly appreciate the time and effort they have put into the task. Additionally, I hope they find my responses to be useful in developing further debate on these topics. ${ }^{1}$

\section{Jan Narveson}

Narveson's article considers the reasonableness of egalitarian political philosophy that was endorse by John Rawls and by me in my article. He brings up many interesting ideas and

\footnotetext{
${ }^{1}$ In addition, I would like to thank the editors of Analyse \& Kritik for soliciting responses to my article. It is deeply appreciated.
} 
criticisms of this position. Unfortunately, I will only be able to respond to one, but one which I think is at the heart of his criticisms. Narveson finds that Rawls' conceptions of fairness and redistribution are undesirable when compared with a conception of fairness that is based on acquisition without the redistribution of property. Specifically, Narveson disagrees that the redistribution of "some people's fairly acquired property is fair" (Narveson 2017, 402). In considering which conception of fairness is the most desirable it is best to revisit Rawls definition of fairness that he provides in A Theory of Justice:

"Since all are similarly situated and no one is able to design principles to favor his particular condition, the principles of justice are the result of a fair agreement or bargain. ... The original position is, one might say, the appropriate initial status quo, and thus the fundamental agreements reached in it are fair.” (Rawls 1999, 11)

Since people have no idea what they wish or what is to their advantage, behind the veil of ignorance, they must craft principles that people in the original position would agree to.

There are two issues in considering fairness for Rawls. First, the original position is defined by Rawls as fair due to the absence of threat advantage. This is supposed to be a situation of moral supremacy compared to our everyday judgements as historical individuals. Thus, our conclusions that are made behind the veil should take precedence over judgments made outside the veil (Rawls 1999, §4 and §78; Rawls 2001, 17 and 102-103). Second, a fair decision making situation allows us to provide an objective hierarchy of goods. The ownership of non-personal property is considered to be of less importance than the enjoyment of our two moral powers, other primary goods, natural goods, and the use of personal property to facilitate 
the enjoyment of these goods. ${ }^{2}$ This means that it is fair to redistribute non-personal property for goods that we find objectively more important (Rawls 1999, §26; Rawls 2001, 99).

Rawls' argument about why redistribution of fairly acquired property is fair is because there are more objectively important goods than the ownership and enjoyment of non-personal property. Without this distinction Rawls found that we are left with a collection of common sense precepts of justice that cannot be reconciled. What is needed is a "higher criterion" that will allow for these precepts to be ordered. Rawls' discussion notes that Mill thought the principle of utility could serve such a role; whereas, Rawls states that the two principles serve this purpose in his own theory (Rawls 1999, 268).

This higher criterion of the two principles can order these precepts that are in conflict in its absence: it is fair to own fairly acquired property and it is fair to redistribute to provide people with the goods noted above. Thus, Narveson's criticism of redistribution needs to be structured with a higher criterion that puts the ownership and enjoyment of non-personal property as more objectively important than the enjoyment of our two moral powers, other primary goods, natural goods, and their facilitation by personal property. Such a conclusion, Rawls held, could not be made behind the veil of ignorance because under these conditions people would find the enjoyment of these goods to be more important than ownership of non-personal property. Guaranteeing people's enjoyment of these goods and personal property is understood as the reasonable solution given no knowledge of ourselves, the conditions of our society, and world we will live in.

Rawls thought that competitors to the two principals have two serial avenues to challenge the two principles. First, they can argue that their conception of justice will be chosen

\footnotetext{
${ }^{2}$ On what personal property may include, in contradistinction to the means of production, see Holt $2017,183$.
} 
behind the veil instead of the two principles. If this fails, then competitors can "object to the setup of the original positon itself as a device of representation" (Rawls 2001, 83). Narveson's notion of fairness would be rejected in the original position. Objecting to the setup of the original position requires a weakening of the limitations on knowledge. This results, at worst, in the loss of objectivity that the veil of ignorance provides, and, at best, a move towards the principle of average utility (Rawls 1999, §27). Both of these results do not get where Narveson wants to be: the consideration that the ownership of fairly acquired property is more important that other goods.

\section{Jeppe von Platz}

Jeppe von Platz provides several criticisms of my article that I will address individually. First, von Platz finds that he is not sure how workplace democracy as a basic political right "could be constructed from Rawls’s writings" (von Platz 2017, 409). One cannot exclude democratic political participation from the basic structure. If the economic is part of the basic structure, then people should have democratic control over the economy in two ways: nationally and at the level of the firm. Nationally economic democracy would allow for the overall regulation, planning, and ownership of all private property and social property. This would include all resources in a nation (that are not personal property) and all the means of production. This level of national economic democracy would allow for not only the control over quantity, price, and pace of output, but also the location and composition of total output. This would be needed for our enjoyment of our social primary goods and our natural goods (Rawls 1999, 54).

Workplace democracy would be additionally required to provide for the protection of natural and social primary goods. The primary goods of self-respect and liberty would appear to 
be more in jeopardy at the level of the firm than the national economy (within a constitutional democracy). Workplace democracy would be a means for people's participation in the overall orchestration of the firm and a means for them to voice their grievances concerning the enjoyment of these two primary goods. Additionally, workplace democracy is a means for people to participate in the social union of their occupation in a reciprocal manner. Reciprocity, as the fair terms of cooperation, appears to require democratic control and participation (Rawls 2001, 6).

Second, von Platz finds that democratic oversight of the economy does not require public ownership of the means of production (von Platz 2017,410). Democratic oversight of the economy does not have to include the explicit and voiced public ownership of the means of production. Nonetheless, democratic oversight allows for regulation, redistribution, and nationalization of the means of production in order for justice to be met. There is no right to private or social ownership of the means of production according to Rawls (Rawls 2001, 114). This means that the owners of property can be changed to meet the demands of justice. This is different than our exclusive use of personal property. A person's personal property can be regulated, but not in any way to meet the demands of justice.

Third, von Platz shows that even though families are part of the basic structure we should allow families to "determine their decision-making processes for themselves, and to leave the reproductive choices of families outside the realm of public regulation" (von Platz 2017, 410). Von Platz is correct about the limits that the public can impose upon the family, as Rawls discussed (Rawls 2001, 165). Von Platz then extends his argument to individual workplaces and private property. Just as a family can regulate its own affairs, an individual firm or person may do so over their private property. It is true that individual families can decide on what is the best 
way for their families to be organized within the boundaries of justice. What also lies within the boundaries of justice is the possibility to change the rules and goals of governance, such as the capacity to alter our laws and change our leaders. Thus, a family can decide that its current system of decision making and its reproductive plans can be altered. When people get married, as Mill pointed out, they do not give up their right to self-rulership (Mill 1997, 32).

Applying this consideration to the workplace or the economy as a whole I think is consistent. When we join a firm we should not be giving up our right to self-rulership. Thus, we should have the ability to alter how decision are made in our firms. This does not mean, contrary to Taylor's reading of Rawlsian liberal socialism, a firm must have all of its members always participate in management (Taylor 2014). A family could decide that a particular adult in their household makes all the decisions, and then they could change their minds and choose a different adult, a committee of them, etc., to make decisions. The same notion applies to a firm. It could be originally set up where the founder-inventor makes all the decisions. This does not always have to be the case. The members of the firm may find that it would be better run if a professional management team was recruited and the founder was left to her inventions.

Fourth, von Platz argues that there is a dilemma between a regulated economy, which is endorsed by Rawls, and an economy that requires liberal socialism, which is not solely endorsed by Rawls (von Platz 2017, 410-411). As I showed in my paper, Rawlsian justice requires that public ownership of the means of production has to be available to a nation if this allows the requirements of justice to be met (Holt 2017, 192-193). If justice can only be met by explicit control of some or all of the means of production by public employees and/or publically elected bodies, then this means that liberal socialism best meets the requirements of justice. This is the case because a liberal socialist society always retains at least nominal ownership of the means of 
production. All other kinds of ownership regimes that prevent public ownership and direct control will place the requirements of justice as secondary. Rawls' neutrality between propertyowning democracy and liberal socialism cannot be maintained if the requirements of justice take precedence over who owns property.

\section{Alan Thomas}

There is one essential point that needs to be responded to at the end of Alan Thomas' article. He states: "So I am not convinced that Holt has demonstrated that LS [liberal socialism] is the only way to express the value of justice as fair reciprocity" (Thomas 2017, 415). As noted above in my response to von Platz, reciprocity, as the fair terms of cooperation, appears to require democratic control and participation (Rawls 2001, 6-7 and 49). At the level of the firm this would either be workplace democracy in either a property-owning democratic regime or a liberal socialist regime. At the level of the national economy reciprocity would require that nonpersonal property be subject to public control. This democratic control allows for the nationalization of a firm, industry, resource, built asset, or intangible asset. Reciprocity may fall short if any non-personal property item cannot be converted from private property into social property. Only a liberal socialist regime has these qualities of control over property. If a nation has the ability to change the ownership of property, even if the ability is not voiced, then this regime is a liberal socialist regime. An example I think will be helpful.

A given industry or sector may better meet the standards of fair cooperation if it is nationalized. There may be numerous problems associated with this industry or sector that could be alleviated if it were subject to national public control. Transportation systems, energy, mining, banking-finance, telecommunications, water, housing development, and urban planning are some 
sectors where coordination failures, adding-up problems, negative externalities, and predation can be commonplace. These issues are failures of reciprocity due to the impossibility of fair cooperation when an industry or sector is operated as a decentralized aggregation of private firms or as private monopolies. With private business the rational interests of firm members take precedence over the demands of reasonable interactions of the members and non-members of firms as citizens. Explicit public control over these industries and sectors may allow for the alleviation of these problems. If they do so, then nationalization would be in order to meet the demands of justice.

There is no reason why the public control of all non-personal property cannot include nominal private ownership for any period of time. This is why I stated that public ownership does not have to be always voiced (Holt 2017, 192). The demands of justice require that nonpersonal property can be subject to public ownership. This capacity for the conversion of nonpersonal property into social property to meet the demands of justice appears to be solely within the domain of liberal socialism. This means that reciprocity is best expressed in a liberal socialist regime. If private property cannot be subject to public control and the use of private property results in outcomes that are detrimental to reciprocity, then this society falls short of the demands of justice. If property-owning democracy does not allow for private property to be nationalized to allow for reciprocity to obtain, then property-owning democracy falls short of the demands of justice. If property-owning democracy does allow for the nationalization of private property for the enjoyment of reciprocity, then this economic regime is actually liberal socialism. The distinctions between property-owning democracy and liberal socialism cannot be maintained if the demands of justice require the public ownership of property. Once justice requires that the 
economy is secondary to what is determined in a fair decision making situation, then the right to private property cannot be considered as basic, unlike personal property (Rawls 2001, 113-114).

\section{Final Comments}

Again I would like to thank Jan Narveson, Jeppe von Platz, and Alan Thomas for their interesting and thoughtful articles. It has been a great joy to provide responses to their engaging ideas. I hope they find my comments to be fruitful, and I hope readers found our exchanges to be of use for their own thinking on these topics. In closing, I have a few final comments.

The control over non-personal property is still an essential question of our age, since the inequalities of ownership impact our enjoyment of opportunities, reciprocity, and liberties. It appears to be impossible to live in a society that we would considered to be freely chosen without the possibility of public control over non-personal property. Rawls' comments on the fundamental question of political philosophy for democratic constitutional regimes is important in this context:

"That question is: what is the most acceptable political conception of justice for specifying the fair terms of cooperation between citizens regarded as free and equal and as both reasonable and rational, and (we add) as normal and fully cooperating members of society over a complete life, from one generation to the next?" (Rawls 2001, 7-8)

I have argued that the fair terms of cooperation allow us to recognize that ownership of nonpersonal property is objectively less important than enjoyment of our two moral powers and social and natural goods. The ownership of private property is not basic because it is unfair to 
make people subordinate their conscience to an institution of lesser importance. It is only possible that people can cooperate as free and equal citizens when justice takes precedence in the determination of property ownership.

\section{References}

Holt, J. (2017), The Requirements of Justice and Liberal Socialism, in: Analyse \& Kritik 39, $171-194$

Mill, J.S. (1997), The Subjection of Women, Mineola/NY

Narveson, J. (2017), ‘Property-Owning Democracy’? 'Liberal Socialism’? Or Just Plain Capitalism?, in: Analyse \& Kritik 39: 413-416

Rawls, J. (1999), A Theory of Justice, revised edition, Cambridge/MA

— (2001), Justice as Fairness: A Restatement, E. Kelly (ed.), Cambridge/MA

Taylor, R. S. (2014), Illiberal Socialism, in: Social Theory and Practice 40, 433-460

Thomas, A. (2017), The Demands of Democratic Ownership, in: Analyse \& Kritik 39: 413-416

Von Platz, J. (2017), Democratic Rights and the Choice of Economic Systems, in: Analyse \& Kritik 39: 405-412 